\title{
The effect of Quantum learning model on foreign language speaking skills, speaking anxiety and self-efficacy of secondary school students*
}

\author{
Mehmet Altın ${ }^{a} \dagger$, Asuman Seda Saracaloğlu ${ }^{b}$ \\ ${ }^{a}$ Aydin Adnan Menderes University, Aydin, 09010, Turkey \\ ${ }^{b}$ Aydin Adnan Menderes University, Aydin, 09010, Turkey

\section{APA Citation:} \\ Altın, M., \& Saracaloğlu, A. S. (2019). The effect of Quantum learning model on foreign language speaking skills, speaking anxiety and self- \\ efficacy of secondary school students. Journal of Language and Linguistic Studies, 15(3), 1083-1104. \\ Submission Date:04 /07/2019 \\ Acceptance Date:08/08/2019
}

\begin{abstract}
Learning English as a foreign language is considered important for different reasons in the world. However, despite the great effort and investment in Turkey, the rate and level of learning English is not at the desired level. This research aimed to determine the effect of quantum learning model on foreign language speaking skills, speaking anxiety and self-efficacy of secondary school learners. Needs analysis was used to determine the subject, model and method of the research. The research was designed in the experimental model. The experimental model was a $3 \times 4$ (experimental, control and placebo group $\mathrm{X}$ pre-test, post-test, retention test, retention monitoring test) semiexperimental model. A pilot implementation was conducted at a seventh grade before the main implementation, and feedback for the main implementation was received. The study group consisted of three seventh grades of a secondary school, achievement level of which was middle. Each class was assigned as control, experimental or placebo group by cluster sampling method. The implementation of curriculums in the groups lasted ten weeks including the application of pre-test and post-test. In conclusion, the curriculum conducted appropriate for quantum learning model increased students' self-efficacy beliefs in English and reduced their English speaking anxiety. However, the contribution of the model to speaking skill was not statistically significant. The activities in English curriculum conducted according to quantum learning model attracted the attention of the students, increased participation in the events, led students to inquire and make research, made the lesson enjoyable.
\end{abstract}

(C) 2019 JLLS and the Authors - Published by JLLS.

Keywords: Quantum learning; self-efficacy; speaking anxiety; speaking skill; teaching English

\section{Introduction}

With the globalization, the amount of information has increased, and it has become compulsory to follow the innovations and developments to obtain this information (Çelebi and Sarıcaoğlu, 2009). It is necessary to communicate with different societies to obtain information. The best tool for international communication is to use a common language. Nowadays, the most commonly used language in the world is English (Demirel, 2012). This popularity of English may be attributed to various reasons such as the colonialist policy of the former British Empire, the current dominance of the United States and

\footnotetext{
* This paper is a summary of $\mathrm{PhD}$ thesis prepared by the first author under the supervision of the second author

${ }^{\dagger}$ Corresponding author. Tel.: +0-543-264-3400

E-mail address: mehmet.altin@adu.edu.tr
} 
the advancement of science and technology in English language, and nearly one billion people have been trying to learn this common language (Maxom, 2009). Nowadays learning English is not only for communication; investment in the future has become an endeavor to utilize leisure time and a goal to be achieved (Tin, 2013). One of the first actions of those who want to change their lives has been learning English as a foreign language (Maxom, 2009). Demirel (2012) states that the development of media and communication technology and the increase in the exchange in international economy, tourism and politics have enhanced the necessity of spreading a common language to the whole world and the desire to learn foreign language. Therefore, learning English has now become a major business field (Maxom, 2009).

Learning English is considered very important in Turkey as in most countries. The number of English courses in curriculums is continuously increased and a lot of effort and expense is made for the language teaching to be effective (Arslan, 2009). In many countries, foreign language courses begin before the third grade of primary school. On the other hand, in Turkey, whereas first given in the 6th grade, foreign language courses were started to be given in fourth grade after 1997; and finally, they have been given in second grade since 2013-2014 academic year (Bekleyen, 2016). When the English courses in the first year and prep classes are calculated, it is found that a student learns English for about 13 years; however, at the end of these years, students cannot reach the intended level of English.

Turkey is a country that has to come up with solutions to the problems occurring in education system, stemming from its geographical and cultural diversity and increase in young population (Çelik and Arıkan, 2012). Today, when foreign language is so important in every field, the studies that are and will be conducted to be able to learn English, which is the leading among the most spoken languages in the world, carry an important value. Teaching English as a foreign language is conducted intensively in Turkey, which is in interaction with different countries. When curriculums are examined, an intensive foreign language curriculum from primary school to university draws attention; however, even though great importance is attached to language acquisition, learners have great difficulty in it. This difficulty is generally associated with the opinion that, as a country, the ability to learn a second language is weak; however, the right thing is to get to the root of the problem, examining it (Arslan, 2009). Needs analyses to be carried out for this purpose are of great importance. Thus, needs analysis was realized in order to determine the subject and method of the study, which is given in the method part.

Today, in an "information society," where knowledge constantly changes, more studies are conducted aimed at learning models that attach importance to learning while being taught, for increasing the number of individuals that have skills of reaching knowledge faster and more efficiently and use these skills in different areas throughout their lives (Hanbay, 2009). Especially in primary and secondary school levels, when individuals' cognitive, affective and psycho-motor skills are developing, learning models have great importance. Another model that may be referred to in different educational levels is quantum learning model. When the body of literature was studied, it was concluded that there isn't any study on quantum learning model related directly to ability to speak a foreign language, foreign language speaking anxiety and foreign language self-sufficiency. With the study conducted, it is thought that the effect of Quantum learning on the ability to speak English, anxiety and self-sufficiency were examined experimentally and it also contributed to the literature concerned because mixed data collection method is used.

\subsection{Quantum learning model}

Quantum is defined as an interaction, which turns energy into light. The whole life is energy. One of the well-known formulas in quantum physics is "substance" multiplied by "light velocity square" equals "energy,"E=mc ${ }^{2}$. DePorter, who defines Quantum, as "the interaction that turns energy into light," 
defines quantum learning model as the interaction of the combination of learning, philosophy and method, the activity of which were proven in education. Besides, he maintains that Quantum learning is an ideal model for learners of every style at every age (DePorter and Hernacki, 1992).

The itinerary in a Quantum based curriculum is not determined beforehand and may be modified in accordance with individuals' needs, interests and styles of learning. A curriculum that internalizes Quantum theory should be based on a connection that will be formed between the mind and the experiment. Cognitive formation contributes to different types of intelligence thanks to emotional and sensual formation. Therefore such a curriculum includes not only cognition but also emotion, thought, intuition and creativity. In 2004, Ministry of National Education has adopted the Quantum theory as scientific philosophy, with changes that will be accepted as reforms. Thereby, with the new curriculum based on Quantum theory, the aim is to educate individuals with holistic and multi-dimensional viewpoints and elastic and questioning mentalities (Ekici, 2013). Kanadlı, Ünal and Karakuş (2015) have maintained that environments organized appropriate for the quantum learning model affect academic success positively.

\subsection{Quantum learning order}

There is a learning order prepared in line with the quantum learning principles, which a teacher has to consider while practicing quantum learning in his/her class (Ayvaz Tuncel, 2011; Deporter, Reardon and Singer-Nourie, 1999; Ekici, 2013):

1. Enrolling: A remarkable entrance is made in order to arouse students' curiosity and learners are informed about the targets before giving detailed information about the topic.

2. Experiencing: An activity is performed, having the characteristics of introduction to the topic, which will help students associate their prior information with the new ones.

3. Labeling: After students' attention is engaged, its relation to the learners' lives is discussed. At this level, learners try to label, sort, classify and define the new information they have learned.

4. Demonstrating: The students are provided with activities, where they adapt the information they learn to different situations. Students gain confidence as they see that they can apply what they have learned in new cases.

5. Reviewing: Information is repeated with activities, in a way that will ensure the proper comprehension of students. The repetition of information strengthens the neuroglia of students and provides permanent learning.

6. Celebrating: The incident of learning is celebrated, since the information obtained is valuable. When the effort, meticulous works and success of the student are rewarded, a positive attitude develops towards learning and the teacher.

The research aims to examine the effect of the English curriculum developed by quantum learning model on the ability of speaking, speaking anxiety and self-efficacy of foreign language students. Depending on the purpose of the research, hypotheses to be looked into and the sub-problems to be answered are given below:

1. There is a statistically significant difference in favor of the experimental group between the pretest, post-test, persistence and permanence monitoring scores among the experimental group and the control and placebo groups where the English curriculum is applied according to the quantum learning model.

2. There is a statistically significant difference in favor of the experimental group between the pretest, post-test, permanence and permanence monitoring scores of the English self-efficacy beliefs among the experimental group and the control and placebo groups where the English curriculum conducted according to the quantum learning model is applied. 
3. There is a statistically significant difference in favor of the experimental group between the pretest, post-test, persistence and permanence of speech anxiety scores among the experimental group and the control and placebo groups where the English curriculum is applied according to the quantum learning model.

4. How did the students react to the curriculum conducted according to the quantum learning model?

5. What are the students' views about the curriculum carried out according to the quantum learning model?

\section{Method}

\subsection{Needs Analysis}

Before the study, needs analysis was realized to determine the subject and method of the study. The needs analysis performed before the study is a phenomenological research. In phenomenological studies, data are collected to describe the basic structure and value of individuals' experiences (Merriam, 2013). In data collection with regard to phenomenological researches, qualitative data collection techniques are utilized such as interview, observation, document and artwork analysis. In qualitative research, verbal or textual data are studied, analyzed and interpreted (Nassaji, 2017). In the needs analysis, interviews and documents were used for data collection. In order to determine the teachers' perceptions, data were obtained from interviews with teachers, and in order to analyze the studies conducted in the field of English teaching, data were obtained from the theses in YÖK thesis system.

Theses were collected by document analysis method in accordance with qualitative research principles. Documentary observation (Duverger, 1973; cited in Karasar, 2012) or the document method (Rummel, 1968; cited in Karasar, 2012), which is also known as document analysis method, consists of the collection of data from written materials containing information about the case or cases targeted to be investigated in accordance with the purpose of the research (Yıldırım and Şimşek, 2004). When a total of 117 theses written in the field of English language teaching in Turkey are examined, it is observed that 97 of them were written for master degree and 20 of them for $\mathrm{PhD}$. It is understood the number of $\mathrm{PhD}$ dissertations are less than the number of master's degree dissertations in the field of English teaching. When the models used in these theses were examined, it was found that 94 theses were designed with a descriptive and 23 of them with an experimental model. It is seen that experimental models are less than descriptive models among the models used in the design of the theses. This may be due to the fact that researchers prefer the descriptive model for reasons such as their belief that describing what exists may be easier than changing it or their disbelief in experimental effect. When the data collection methods applied in theses are analyzed, it has been seen that the data in 61 theses are collected with qualitative method, the data in 37 theses with mixed and the data in 19 theses with quantitative methods. It is understood that regarding the data analyzed in the theses, the preferred data collection method was qualitative method and mixed and quantitative methods were less utilized.

In the needs analysis, the data obtained from the teachers' opinions received to determine teachers' perceptions regarding the skills, subjects and units that the students had difficulty in, were analyzed. In the study, it was concluded that the learners were not concerned with the teaching methods and techniques in four main language skills and had difficulties concerning some vocabulary types, grammar structures and units. Also, the importance they gave to classes decreased together with adolescence and their motivation decreased because their English scores were lower than the scores of other courses in the high school entrance exam. The teachers also stated that the ability to speak a foreign language is a troublesome issue in our country. The teachers told that students frequently make pronunciation 
mistakes regarding their speaking abilities. Besides, there are also teachers who assert that students refrain from speaking. Öner and Gedikoğlu (2007) emphasize that students must be reminded not to get anxious about making mistakes and that they must be corrected appropriately. In the study conducted by Koch and Terell (1991; cited inAydin and Zengin, 2008), it was found that talking in front of other students in foreign language class emerged as a source of anxiety, whereas in the study conducted by Phillips (1992; cited in Aydın and Zengin, 2008), it was suggested that learners with a high level of anxiety delivered their performances using a small number of structures.

\subsection{Research model}

The experimental model was applied in the study. The experimental model to be used in this study was designed according to 3X4 (experimental, control and placebo group $\mathrm{X}$ pre-test, post-test, permanence test and permanence monitoring test) quasi-experimental model. Alongside the control group, placebo group was also included to demonstrate that the change that might occur in the experimental group stems from the applied curriculum.

\subsection{Study group}

The school, where application will be made with multi-stage sampling method and one of the seventh grade classes of the school was selected as experimental, one placebo and one control group. Multistage sampling involves multiple steps (Balc1, 2015). First of all, the socio-economic level list of 46 secondary schools in the district was reached from the Research-Development Unit of the Directorate of National Education. Throughout the needs analysis study, study was conducted on mid-range schools for similar reasons -in order to generalize the obtained findings to include the schools in Turkey. The schools in the middle group were determined according to the list. Among these, schools which have at least three 7th grade classes were determined and one of them was chosen randomly. By cluster sampling method, one of the three classes was assigned as a control, one as an experiment and one as a placebo group. Information about the students participating in the study is given in Table 1.

Table 1. Gender of the participants

\begin{tabular}{cccc}
\hline Group & \multicolumn{3}{c}{ Gender } \\
\hline Test & Female & Male & Total \\
Control & 17 & 15 & 36 \\
Placebo & 15 & 20 & 37 \\
Total & 53 & 55 & 35 \\
\hline
\end{tabular}

\subsection{Data collection}

In the study conducted after the needs analysis, mixed research method was applied as data collection method. Mixed method is a type of research in which qualitative and quantitative data or methods are used together in a single study (Christensen, Johnson and Turner, 2015). In the mixed method, the researcher gathers and examines both qualitative and quantitative data based on research questions. S/he blends both of data types at the same time, by placing this data type, one of these data types in the other or by building one on top of the other in turn; s/he gives priority to one of the data types or both of them according to the emphasis of the research. S/he uses these operations in a single study or in more than 
one phase of a work curriculum. S/he frames these operations, within the context of philosophical world views and theoretical perspectives and combines these operations with the special research pattern, which guides the study conducting curriculum (Creswell and Clark, 2015). Quantitative data were analyzed with the measurement tools and scoring key used in the experimental model; and qualitative data were collected by diversification strategy. Diversification is the totality of efforts to increase the credibility of the research results by using several data sources, several data collection and analysis methods (Yıldırım and Şimşek, 2008). Methods used in diversification are interview, observation and document review. During the curriculum implementation, the course teacher and the researcher kept field notes. Field notes are written records of the actions taken in the classroom (Johnson, 2015). There were also record books, in which, at the end of each course, the participants in the experimental group wrote their thoughts about the course. Record books are the diaries, in which participants convey their thoughts and assessments (Johnson, 2015). Following the implementation of the curriculum, interviews were conducted with volunteers from the groups of three students with the highest, medium-level and lowest scores in grading key in the experimental group. The interview questions were designed to determine the students' perceptions and feelings towards the curriculum applied to the group in which are participants from the experimental group.

In all the three groups, the course was conducted by the teacher. The conduct of teaching in the groups lasted eight weeks. Scales and grading key were applied before and after teaching. The pilot implementation of the curriculum applied in the experimental group was performed, and the actual implemented curriculum was updated in line with the feedback of the practitioners and participants. While the curriculum based on the quantum learning model was applied on the experimental group, the control group carried on with the normal curriculum. The technique, in which the texts in the normal curriculum were read aloud and the pronunciation errors were immediately corrected were applied on the placebo group, unlike the control group. This technique is especially used for the purpose of improving the pronunciation in the direct method (Larsen and Freeman, 2003). Pre-test was applied on the groups before the implementation of curriculums, post-test, following the implementation of curriculums, permanence test, two months after the implementation of curriculum and permanence monitoring test, four months after the permanence test. The scoring speaking skill was made by the teacher and researcher in the grading key, and the harmony between raters was examined.

\subsection{Data collection tools}

\subsubsection{English self-sufficiency belief scale}

Self-sufficiency belief scale related to English is a 34-item likert type scale developed by Hanc1 Yanar and Bümen (2012). Reliability of the scale according to Cronbach's alpha coefficient is 94. The scale consists of four sub-dimensions. The first eight items are related to "reading", the next 10 items "writing," the following 10 items "listening," and the last six items are related to "speaking" skills. The scale items were scored within the ranges "Fits me completely (5)", "Fits a lot (4)", "Fits slightly (3)", "Fits a little (2)" and "Does not fit me at all (1)". The lowest score which can be gathered from the scale is 34 , and the highest score is 170 . The author was contacted for the use of the scale and required permission was obtained.

Confirmatory factor analysis was applied to examine the compatibility of the data collected with the self-sufficiency belief scale. Since the relationship between the writing and listening dimensions in the model was greater than 90, these two dimensions were combined under the "writing and listening" dimension, in order to eliminate the multicollinearity problem. Listening and writing skills can be considered as distant skills; however, listening skill is the most important skill for one's writing skill. One can write what s/he has heard or read. In other words, listening skill has a crucial role in the improvement of writing skill (Emiroğlu and Pınar, 2013). Accordingly, the unification of listening and 
writing skills in one dimension can be considered valid. The findings obtained from the compatibility of the dimensions in the model are shown in Table 2.

Table 2. The results of the self-sufficiency scale confirmatory factor analysis regarding English

\begin{tabular}{ccccccc}
\hline Scale & $\mathrm{X}^{2}$ & sd & $\mathrm{X}^{2} / \mathrm{sd}$ & RMSEA & CFI & IFI \\
\hline IOO & 1154.21 & 524 & 2.2 & .07 & .9 & .91 \\
\hline
\end{tabular}

When Table 2 is examined, high values of CFI and IFI indicate that the compatibility is good. Besides, the value of $\mathrm{X}^{2} / \mathrm{sd}$ is 2.2 . Some authors comment that this value's being less than 3 indicates that the general consistence of the model is acceptable (Meydan and Şeşen, 2015). If the RMSEA value is less than .08 , it shows that the model is acceptable.

Collected data were analyzed with Cronbach's alpha coefficient. The reliability coefficient obtained for both the sub-dimensions and the whole of the scale is higher than 9. This value shows that the scale is highly reliable.

Table 3. Reliability coefficient obtained for English self-sufficiency belief scale

\begin{tabular}{lcc}
\hline \multicolumn{1}{c}{ Dimension } & Number of Items & Cronbach's Alpha Coefficient \\
\hline Reading & 8 & .95 \\
Writing and Listening & 20 & .97 \\
Speaking & 6 & .92 \\
Full Scale & 34 & .98 \\
\hline
\end{tabular}

\subsubsection{Foreign language speaking anxiety scale}

Foreign language speaking anxiety scale is a 32 point likert-type scale developed by Horwitz, Horwitz and Cope (1986). .This scale, reliability of which was 93 according to Cronbach's alpha coefficient, was adapted to Turkish by Aydın (1999). Saltan (2003) selected and used 18 items of this 32-item scale. Öztürk (2012) calculated the reliability of the 18-item scale according to Cronbach's alpha coefficientas 91 and used this scale in his study. The adapted scale consists of four dimensions and a total of 18 items. Communication anxiety is measured in items 1, 5, 7, 9, 13 and 15, fear of negative evaluation in items $3,6,8,11,12,17$ and 18, exam anxiety in 2nd and 10th items and anxiety in the English class in items 4, 14 and 16. The scale items were scored within the ranges "Strongly disagree (1)", "Agree (2)", "No idea (3)", "Agree (4) "and "Strongly agree (5) ". The lowest score of the scale is 18 and the highest score is 90 .

For collecting the data needed for the examination of the validity and reliability of the "Foreign Language Speaking Scale", to be used in the study, a total of 239 students from seventh grades of two middle socio-economic level secondary schools were reached. Data obtained from 239 students were used for the validity and reliability study.

Confirmatory factor analysis was applied to applied the consistency of the data collected with the Foreign Language Speaking Scale. Since the relationship between the dimensions in the model is higher than 9, the model was reduced to one size. The findings obtained from the compatibility of the dimensions in the model are given in Table 4. 
Table 4. English speaking anxiety scale confirmatory factor analysis results

\begin{tabular}{ccccccc}
\hline Scale & $\mathrm{X}^{2}$ & $\mathrm{sd}$ & $\mathrm{X}^{2} / \mathrm{sd}$ & RMSEA & CFI & IFI \\
\hline IKKKÖ & 594.32 & 135 & 4.4 & .00 & .90 & .9 \\
\hline
\end{tabular}

When Table 4 is examined, the CFI and IFI values'being higher than 85 indicates acceptable compliance. Besides, the value of $\mathrm{X}^{2} / \mathrm{sd}$ is 4.40 . Some authors state that the model can be accepted if this value is less than 5 (Meydan and Şeşen, 2015). If the RMSEA value is smaller than 05, this indicates the success of the model formed. The Cronbach alpha coefficient of the collected data was calculated. The reliability coefficient obtained for the whole scale is 98 . This value shows that the scale is mostly reliable.

\subsubsection{Speaking skill grading key}

Speaking skill grading key is a 30-point Likert type scale developed by Saday (2007) through observing his 8 th grade students. With the approval of experts, the test was validated. The test consists of a total of five parts; affective characteristics (1.-5. items), listening (6.-10. items), grammar (11.-15. items, vocabulary (16.-18. items), fluency (19.-22. items), pronunciation (23.-25. items), meaning information (26.-30. items). The highest score to be obtained from the test is 150 and the lowest score is 30 .

Before the grading key was used by the researcher, literature and the English curriculum were scanned and an updated assessment and evaluation was presented to a curriculum development expert. After the expert opinion was received, the grading key, the pilot scheme of which was performed was put into its final form. The new grading key consists of a total of 22 items.

\subsubsection{Semi-structured interview form}

The researcher was developed a semi-structured interview form to be applied in the interviews. After the interview form was prepared, it was given to the approval of two curriculum development experts regarding its validity. The form, revised with feedback from experts, was finalized with pilot scheme interviews conducted with two students in the 7 th grade.

\subsubsection{Field notes}

Field notes were kept by the teacher and the researcher. The teacher recorded his observations of student behavior in the gaps on the implemented curriculum given to him. On the other hand, the researcher used an observation form divided into six parts, being "enrolling/ experiencing/ labeling/ demonstrating/ reviewing/ celebrating."

\subsubsection{Student diaries}

At the end of each lesson, diaries were prepared for the students to write their opinions about that lesson. On every page of the diaries, the activities of the day are given at the start of lines and there are questions about how the course went, what they felt and how their performances were in the columns. They expressed their opinions about each activity in the class by writing them on the relevant cell.

\subsection{Data analysis and interpretation}

For the analysis of quantitative data, firstly SPSS input of the data collected through scales and grading key was made. One-way ANOVA was used to measure the differences among groups after data entry. In the grading key, the concordance between the scores of two different raters was examined by Kendall's compliance test. 
Data obtained from field notes and interviews held during the application were analyzed using content analysis technique. In content analysis, similar data is brought together within the framework of certain concepts and themes, organized and interpreted in an understandable manner (Y1ldirım and Şimşek, 2004). Content analysis that is mostly applied in qualitative studies, is an analysis technique which is used to quantify some properties of written texts numerically and acts as a bridge between the qualitative analysis and statistical results of the material (Bauer, 2003; cited in Göktaş et al., 2012). The data obtained from the logs kept by the experimental group students and document analysis in the needs analysis section were analyzed using descriptive analysis technique. The data gathered in descriptive analysis are summarized and interpreted in terms of predetermined themes (Yıldırım and Şimşek, 2008). Yıldırım and Şimşek (2008) describe the descriptive analysis in four stages: 'creating a framework for analysis, processing data according to thematic framework, defining and interpreting findings'. After the data were analyzed, their frequency distributions (f) and percentages (\%) were given. Balc1 (2015) stated that, in researches where qualitative data collection methods are used, frequency distribution and percentage may be provided and quantification made in the examination of the verbal data obtained. For the reliability of the analyses, the data were coded by both experts and the consistency between the encoders was examined. In addition, direct excerpts from the raw data were included in the findings gathered from the data analysis process.

\subsection{Development and implementation of curriculum}

In order to better understand the quantum learning model, to determine the problems during the application and to make corrections, it was decided to apply a pre-implementation of English curriculum as a pilot scheme according to quantum learning model. In accordance with the acquisitions of the curriculum, the 12-hour curriculum for the 7th grade English course was arranged according to the quantum learning model. Reading passages and listening texts in Birincioğlu Kaldar's (2016) book, which was used as a course book in the 2016-2017 education period, were utilized. The curriculum, which was organized in accordance with the quantum learning model, was broached to three curriculum development experts. Revised according to feedback, the curriculum was implemented in the 7th grade of a secondary school with a medium socio-economic level.

Parallel to the curriculum to be implemented to the experimental group and in accordance with the achievements of the normal curriculum, a 28 -hour curriculum was prepared for the experimental group by taking advantage of the findings obtained from the 12-hour pilot curriculum developed for the 7th grade English course. The curriculum was broached to two experts, one of whom is an expert in foreign language education and the other in curriculum development and instruction. The curriculum was finalized through feedback from experts.

The researcher participated in the curriculum in the experimental group as observer. In addition, for the teacher to be able to take field notes, a sample of the curriculum was prepared and handed over to the teacher so that the teacher could take notes on it. Students' diaries are the data sources in the document review part of the research. At the end of the implementation of curriculum, nine learners from the experimental group were interviewed. Thus, the data were collected through a diversification strategy - three different qualitative data collection techniques. 


\section{Results}

\subsection{Findings obtained from the analysis of quantitative data and interpretation}

The data to be analyzed for the testing of hypotheses were collected from Self-sufficiency Belief Scale regarding English, Foreign Language Anxiety Scale, English Speaking Grading Key and three classes assigned as experimental, control and placebo groups of the secondary school chosen for thesis practice. Data were collected as pre-test, post-test, permanence test and permanence monitoring test. The pre-test was collected in the second week of October, the post-test in the first week of December, the permanence test in the first week of February and the permanence monitoring test in the first week of June. Self-sufficiency belief scale regarding English and the scale of anxiety in speaking a foreign language used for the collection of data, were completed by the students. Students were given a topic on which they can speak in foreign language and their speaking skills were evaluated by two raters (teacher of the course and researcher), using speaking skill grading key. When Kendall's fit coefficient was examined, the two raters were compared regarding their evaluations of the pretest $(\mathrm{W}=.81)$, the final test $(\mathrm{W}=.82)$, permanence $(\mathrm{W}=.83)$ and permanence monitoring $(\mathrm{W}=.79)$ and a meaningful agreement was found statistically between their evaluations $(\mathrm{p}<.01)$. Kendall's coefficient of concordance has values between 0 and 1, and the value's being close to 1 indicates a high agreement between the scores (Can, 2014). The data filled by the instructor of the course as the speaking skill grading key were used in the analysis.

\subsubsection{Findings of the first hypothesis of the research}

In this section, the findings gathered from the analysis performed to test the first hypothesis of the research were included. The hypothesis concerned was: "There is a meaningful statistical difference in favor of the experimental group between the pre-test, post-test, permanence and permanence monitoring points of the experimental group, control group and placebo group, on which English curriculum developed by quantum learning model was applied."

Table 5. English speaking skill pre-test and post-test difference scores of groups

\begin{tabular}{cccccc}
\hline Source of the Variance & Sum of Squares & sd & Average of Squares & $\mathrm{F}$ & $\mathrm{p}$ \\
\hline Inter-group & 422.47 & 2 & 211.24 & 1.975 & .14 \\
Intra-group & 11232.82 & 105 & 106.98 & & \\
Total & 11655.3 & 107 & & & \\
\hline
\end{tabular}

The mean scores of the three groups were compared with one-way analysis of variance in order to test whether there was a difference between the pre-test and post-test difference scores of their English speaking skills. At the end of the analysis, no statistically meaningful difference was observed between the mean of the experimental group participants $(X=-4.39)$, the average of the control group participants $(\mathrm{X}=.27)$ and placebo group participants $(\mathrm{X}=-.97) .\left(\mathrm{F}_{(2-105)}=-.9714, \mathrm{p}>.05\right)$. 
Table 6. The groups' difference scores of English speaking skill post-test and permanence test

\begin{tabular}{lccccc}
\hline \multicolumn{1}{c}{$\begin{array}{c}\text { Source of the } \\
\text { Variance }\end{array}$} & $\begin{array}{c}\text { Sum of } \\
\text { Squares }\end{array}$ & sd & $\begin{array}{c}\text { Average of } \\
\text { Squares }\end{array}$ & $\mathrm{F}$ & $\mathrm{p}$ \\
\hline Inter-group & 14.67 & 2 & 7.34 & .066 & .94 \\
Intra-group & 11700.76 & 105 & 111.44 & & \\
Total & 11715.44 & 107 & & \\
\hline
\end{tabular}

The mean scores of the three groups were compared with one-way analysis of variance in order to test whether there was a difference between the pre-test and post-test difference scores of their English speaking skills. At the end of the analysis, no meaningful difference was observed between the mean of the experimental group participants $(X=-.056)$, the mean of the control group participants $(X=.62)$ and placebo group participants $(X=-.23)$ in statistical terms $\left(\mathrm{F}_{(2-105)}=-.07, \mathrm{p}>.05\right)$.

Table 7. Difference scores of English speaking skill permanence test and permanence monitoring test of groups

\begin{tabular}{lccccc}
\hline \multicolumn{1}{c}{$\begin{array}{c}\text { Source of the } \\
\text { Variance }\end{array}$} & $\begin{array}{c}\text { Sum of } \\
\text { Squares }\end{array}$ & sd & $\begin{array}{c}\text { Average } \\
\text { of Squares }\end{array}$ & $\mathrm{F}$ & $\mathrm{p}$ \\
\hline Inter-group & 223.24 & 2 & 111.62 & .923 & .4 \\
Intra-group & 12694.64 & 105 & 120.9 & & \\
Total & 12917.88 & 107 & & \\
\hline
\end{tabular}

The mean scores of the three groups were compared with one-way analysis of variance in order to test whether there was a difference between the pre-test and post-test difference scores of their English speaking skills. At the end of the analysis, no meaningful difference was observed between the mean of the experimental group participants $(X=1.81)$, the mean of the control group participants $(X=-1.65)$ and the placebo group participants $(X=-.43)$ in statistical terms $\left(F_{(2-105)}=-.923, p .05\right)$.

The mean changes in English speaking skill scores of the groups are shown in Figure 1.

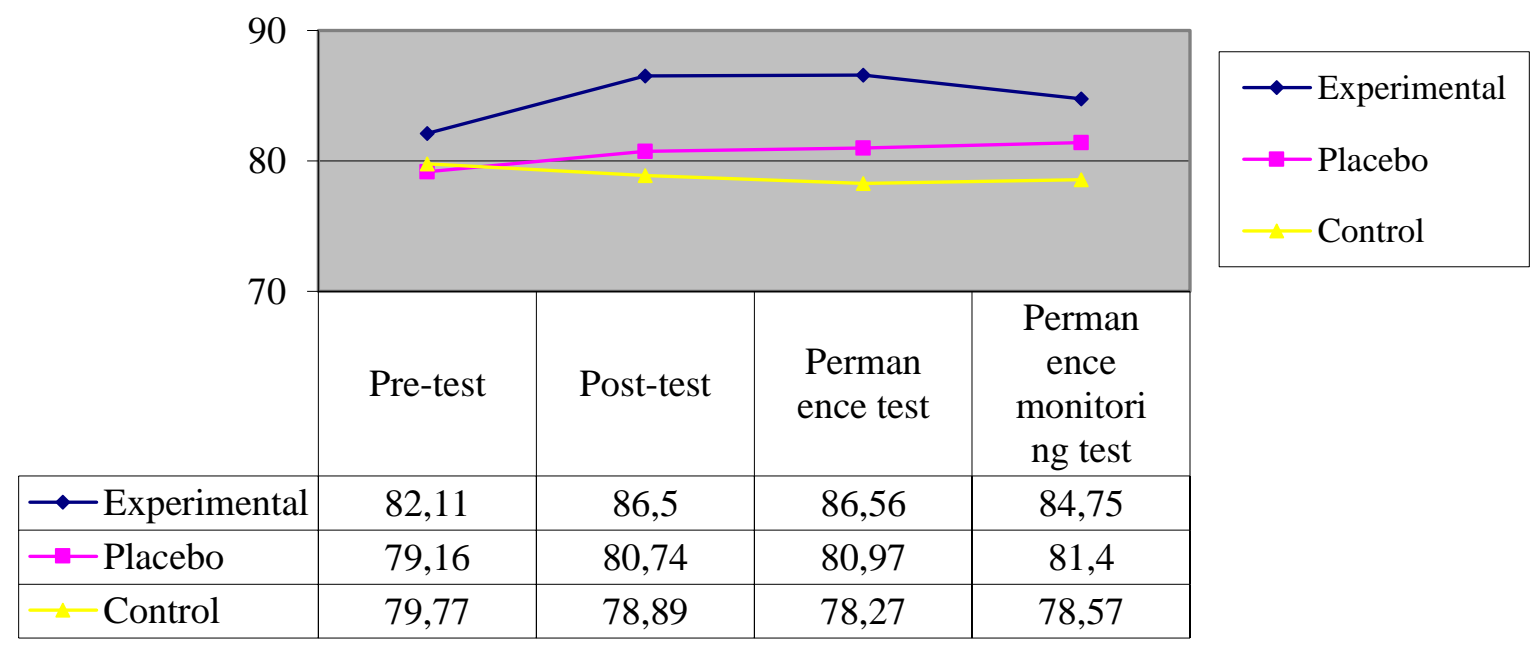

Figure 1. Variation of speech ability point average of groups 
Although no significant difference was found in the wake of the analysis, when Figure 1 is examined, it is seen that the difference between the pre-test and post-test points of the experimental group is greater than the difference between the pre-test and post-test scores of the other two groups. If the experimental application is continued for a while, it can be estimated from the acceleration of the increase that this difference can grow further. Thus, the difference between the groups could become statistically significant. In addition, there is a pause or decrease beginning from the post-test scores and extending to permanence test scores of all groups. The teacher was interviewed regarding this table, and s/he stated that this state of pause or decrease in post-test and permanence test scores of students stems from the weakening of their skills due to entering the semester break. S/he also stated that students in the experimental group were disappointed when they returned to their normal curriculums after the experimental practice was finalized and that their motivation decreased. It can be interpreted that this situation leads to the loss of the positive effect of the model on speaking ability and the rising momentum.

\subsubsection{Findings regarding the second hypothesis of the research}

In this section, the findings gathered from the analysis conducted to test the second hypothesis of the research were included. The hypothesis concerned was: "There is a meaningful statistical difference in favor of the experimental group between the English self-sufficiency beliefs pre-test, post-test, permanence and permanence monitoring scores of the experimental group, control group and placebo group, on which English curriculum developed by quantum learning model was applied."

Table 8. English speaking skill pre-test and post-test difference scores of groups

\begin{tabular}{ccccccc}
\hline $\begin{array}{c}\text { Source of the } \\
\text { Variance }\end{array}$ & $\begin{array}{c}\text { Sum of } \\
\text { Squares }\end{array}$ & sd & $\begin{array}{c}\text { Average of } \\
\text { Squares }\end{array}$ & F & $\mathrm{p}$ & $\begin{array}{c}\text { Significant } \\
\text { Difference }\end{array}$ \\
\hline Inter-group & 3587.79 & 2 & 1793.89 & 6.39 & .00 & Experimental/Control \\
Intra-group & 29485.13 & 105 & 280.81 & & & Experimental/Placebo \\
Total & 33072.92 & 107 & & & \\
\hline
\end{tabular}

The mean scores of the three groups were compared with one-way analysis of variance in order to test whether there was a difference between their English speaking anxiety pre-test and post-test difference scores. At the end of the analysis, no meaningful difference was observed between the mean of the experimental group participants $(X=-12.61)$, the average of the control group participants $(X=.03)$ and placebo group participants $(\mathrm{X}=-.8)$ in statistical terms $\left(\mathrm{F}_{(2-105)}=6.388, \mathrm{p}<.05\right)$. The effect size calculated following the test $\left(\eta^{2}=.11\right)$ shows that this difference is large. Regarding the values that Eta square will have, 01 value is considered small, 06 value medium and 14 value is interpreted as a large effect size (Green and Salkind, 2005; cited in Can, 2014). Following the Tukey multiple comparison test, it is seen that the significant difference is in favor of the experimental group, between the experimental group and the control group and the experimental group and the placebo group. 
Table 9. The groups' difference scores of English speaking anxiety post-test and permanence test

\begin{tabular}{lccccc}
\hline Source of the Variance & $\begin{array}{c}\text { Sum of } \\
\text { Squares }\end{array}$ & sd & $\begin{array}{c}\text { Average of } \\
\text { Squares }\end{array}$ & $\mathrm{F}$ & $\mathrm{p}$ \\
\hline Inter-group & 1922.08 & 2 & 961.04 & 2.513 & .09 \\
Intra-group & 40151.89 & 105 & 382.4 & & \\
Total & 42073.96 & 107 & & \\
\hline
\end{tabular}

The mean scores of the three groups were compared with one-way analysis of variance in order to test whether there was a difference between their English speaking anxiety post-test and permanence test difference scores. At the end of the analysis, no meaningful difference was found between the mean of the experimental group participants $(X=-9.94)$, the average of the control group participants $(X=.84)$ and placebo group participants $(\mathrm{X}=-1.17)$ in statistical terms $\left(\mathrm{F}_{(2-105)}=2.513, \mathrm{p}>.05\right)$.

Table 10. Difference scores of English speaking skill permanence test and permanence monitoring test of groups

\begin{tabular}{lccccc}
\hline $\begin{array}{c}\text { Source of the } \\
\text { Variance }\end{array}$ & $\begin{array}{c}\text { Sum of } \\
\text { Squares }\end{array}$ & sd & $\begin{array}{c}\text { Average } \\
\text { of } \\
\text { Squares }\end{array}$ & F & p \\
\hline Inter-group & 29.8 & 2 & 14.9 & .042 & .96 \\
\hline Intra-group & 37037.87 & 105 & 352.74 & \\
\hline Total & 37067.67 & 107 & & \\
\hline
\end{tabular}

The mean scores of the three groups were compared with one-way analysis of variance in order to test whether there was a difference between their English speaking anxiety permanence test and permanence monitoring test difference scores. At the end of the analysis, no meaningful difference was observed between the mean of the experimental group participants $(X=-1.67)$, the average of the control group participants $(X=.73)$ and placebo group participants $(X=-.43)$ in statistical terms $\left(F_{(2-105)}=-.04\right.$, $\mathrm{p}>.05)$.

The changes in the mean scores of English anxiety of the groups are shown in Figure 2.

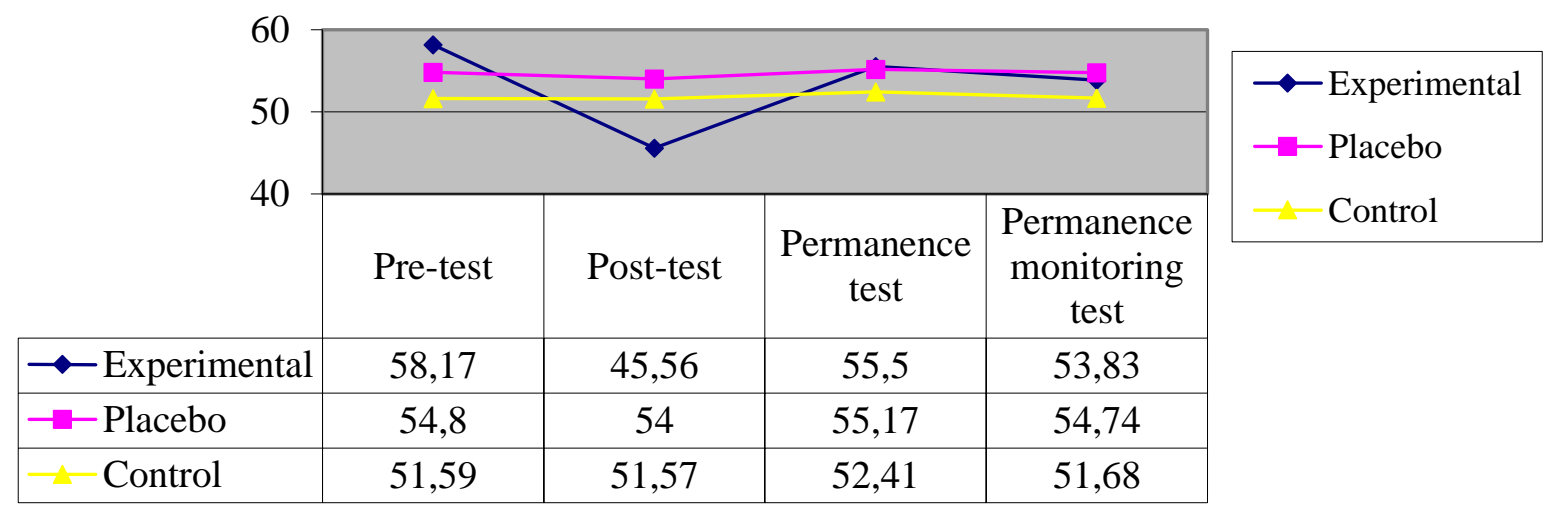

Figure 2. Change in the mean speaking anxiety score of groups 
When Figure 2 is examined, it can be realized that the difference between the pre-test and post-test scores of the experimental group is far greater than the difference among the pre-test and post-test scores of the other two groups. However, there is an increase in the permanence test anxiety scores between the post-test anxiety scores of all groups. In the interview held with the teacher, it was maintained that the students' anxiety increased between the post-test and permanence tests, because they entered the semester break and the permanence test was applied in the first week of the second semester and there were some negative psychological reasons regarding the transition period of students whose holiday had ended and who started a new term.

\subsubsection{Findings of the third hypothesis of the research}

In this section, the findings gathered from the analysis realized to test the third hypothesis of the research were included. The hypothesis concerned was: "There is a meaningful statistical difference in favor of the experimental group between the speaking anxiety pre-test, post-test, permanence and permanence monitoring scores of the experimental group, control group and placebo group, on which English curriculum developed by quantum learning model was applied."

Table 11. The groups' English self-sufficiency belief pre-test and post-test difference scores

\begin{tabular}{ccccccc}
\hline $\begin{array}{c}\text { Source of the } \\
\text { Variance }\end{array}$ & $\begin{array}{c}\text { Sum of } \\
\text { Squares }\end{array}$ & sd & $\begin{array}{c}\text { Average } \\
\text { of Squares }\end{array}$ & F & $\mathrm{p}$ & Significant Difference \\
\hline Inter-group & 5436.24 & 2 & 2718.12 & 6.83 & .00 & Experimental/Control \\
$\begin{array}{c}\text { Intra-group } \\
\text { Total }\end{array}$ & 41808.83 & 105 & 398.18 & & & Experimental/Placebo \\
\hline
\end{tabular}

The mean scores of the three groups were compared with one-way analysis of variance in order to test whether there was a difference between their English speaking anxiety pre-test and post-test difference scores. At the end of the analysis, a statistically significant difference was found between the mean of the experimental group participants $(X=-17.11)$, the mean of the control group participants $(X=$ $-1.62)$ and the mean of the placebo group participants $(X=-2.57)\left(F_{(2-105)}=6.826, p<.05\right)$. The effect size calculated following the test $\left(\eta^{2}=.12\right)$ shows that this difference is large. Following the Tukey multiple comparison test, it is suggested that the significant difference is in favor of the experimental group, between the experimental group and the control group and the experimental group and the placebo group.

Table 12. The groups' English self-sufficiency belief pre-test and post-test difference scores

\begin{tabular}{ccccccc}
\hline $\begin{array}{c}\text { Source of the } \\
\text { Variance }\end{array}$ & $\begin{array}{c}\text { Sum of } \\
\text { Squares }\end{array}$ & sd & $\begin{array}{c}\text { Average of } \\
\text { Squares }\end{array}$ & F & p & $\begin{array}{c}\text { Significant } \\
\text { Difference }\end{array}$ \\
\hline Inter-group & 3841.52 & 2 & 1920.76 & 3.52 & .03 & Experimental/Control \\
Intra-group & 57263.25 & 105 & 545.36 & & & \\
Total & 61104.77 & 107 & & & & \\
\hline
\end{tabular}

The mean scores of the three groups were compared with one-way analysis of variance in order to test whether there was a difference between their English speaking anxiety pre-test and post-test difference scores. At the end of the analysis, statistically significant difference was observed between the mean of the experimental group participants $(X=14.44)$, the mean of the control group participants $(X=1.19)$ and the mean of the placebo group participants $(X=2.54)\left(F_{(2-105)}=3.52, p<.05\right)$. The effect 
size calculated following the test $\left(\eta^{2}=.06\right)$ shows that this difference is moderate. Following the Tukey multiple comparison test conducted, it is seen that the meaningful difference is in favor of the experimental group, between the experimental group and control group.

Table 13. The groups' English self-sufficiency belief permanence test and permanence monitoring test difference scores

\begin{tabular}{cccccc}
\hline Source of the Variance & $\begin{array}{c}\text { Sum of } \\
\text { Squares }\end{array}$ & sd & $\begin{array}{c}\text { Average } \\
\text { of Squares }\end{array}$ & $\mathrm{F}$ & $\mathrm{p}$ \\
\hline Inter-group & 2.97 & 2 & 1.49 & .003 & .99 \\
Intra-group & 52241.1 & 105 & 497.53 & & \\
Total & 52244.07 & 107 & & & \\
\hline
\end{tabular}

The mean scores of the three groups were compared with one-way analysis of variance in order to test whether there was a difference between their English speaking anxiety permanence test and permanence monitoring test difference scores. At the end of the analysis, no meaningful difference was observed between the mean of the experimental group participants $(X=1.44)$, the mean of the control group participants $(\mathrm{X}=1.51)$ and the mean of the placebo group participants $(\mathrm{X}=1.83)$ in statistical terms $\left(\mathrm{F}_{(2-105)}=.003, \mathrm{p}>.05\right)$.

The changes in the English self-sufficiency belief point average of groups are shown in Figure 3.

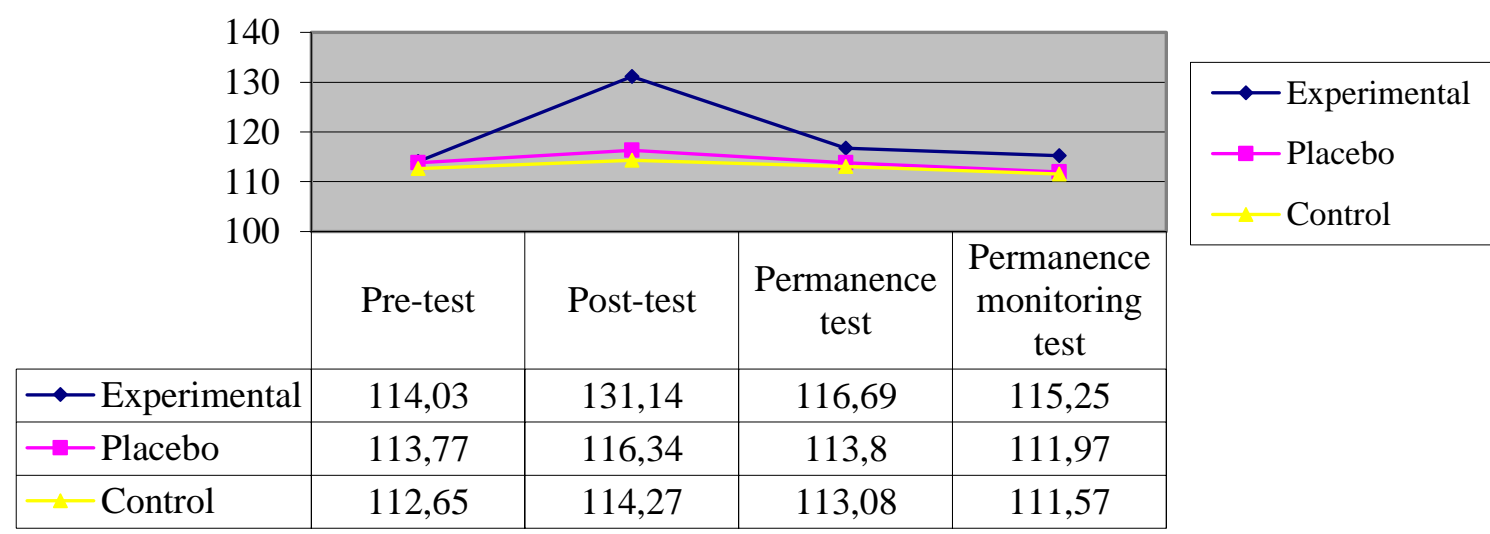

Figure 3. Change of Groups' English Self-Sufficiency Point Average

When Figure 3 is viewed, it is noticed that the difference between the pre-test and post-test scores of the experimental group is far greater than the pre-test and post-test scores of the other two groups. However, there is a decrease between the post-test self-sufficiency scores and monitoring test selfsufficiency scores of all groups. The teacher of the course associated this situation with some psychological and physiological reasons such as the fatigue students experienced in the second term and their inability to rest in the semester holiday. Besides, s/he expressed his/her opinion that not only the students' but also the teachers' performances decreased, their fatigue increased and their willingness to study lessened with the seasonal effect-hot weather. 


\subsection{Findings obtained from the analysis of qualitative data and commentary}

The problems for which answers were sought with the analysis of data collected with the qualitative data collection method in the study, were "How did the students react to the curriculum run in accordance with the quantum learning model?" and "What are their thoughts concerning the curriculum run in accordance with the quantum learning model?". The data to be analyzed for the problems to be solved were collected through field notes, interviews and diaries. The data collected were analyzed with descriptive or content analysis, in accordance with the qualification of the data collection tools. The data collected were analyzed by two professors, expert in the field of qualitative design researches and consistency was provided between the coders, with regard to the reliability of the study.

\subsubsection{Findings regarding the first sub problem of the research}

For the student responses regarding the curriculum run in accordance with the quantum learning model to be determined, the data obtained through the observation of the researcher and the notes that the teacher took on the curriculum were analyzed.

\subsubsection{Findings obtained from the researcher's field notes}

When the findings obtained from the examination of the participants in the experimental group were studied, the findings reached were that, the activities in English classes, which were taught according to the quantum learning model attracted the students' attention and arose their awareness, motivated them, led them to question and research and rendered the lesson fun. However, students were observed to be unwilling and bored, even if just a tad, in the exhibition and repetition parts of the lesson. The reason for this may be that in the activities of those parts, the course book, which students found boring and the listening texts, which strained them were used.

\subsection{Findings obtained from the field notes of the teacher}

Following the content analysis of the notes that the teacher took on the curriculum, it was found that the students joined the activities, they were willing, they payed attention, liked the activities and thought they were fun. However, it was commented that, in the exhibition and repetition parts, they got bored of the book activities and had difficulties in some writing and listening activities.

\subsection{Findings regarding the second sub problem of the research}

The data collected from the diaries kept by students and the interviews made with them were analyzed for determining the learners' views concerning the curriculum run with the quantum learning model.

\subsubsection{Findings obtained from the students' diaries}

Based on the findings gathered from the descriptive analysis of the notes that the students took on their diaries, it was commented that students liked the activities, thought they were fun, the lesson went well, but from time to time, some students did not like the exhibition and repetition parts in which there were activities used in the book and they got bored.

Based on the findings gathered from the descriptive analysis of the notes that the students took on their diaries, it is observed that students were happy throughout the activities, they felt good and had fun. It was commented that the model succeeded in affecting the students' feelings towards the English course positively and reducing anxiety. When considering findings, it was also seen that the learners mostly found their performances good in the activities and were active. It was commented that the model enables students to see themselves as self-sufficient in the lesson.

\subsubsection{Findings gathered from the interviews with students}

Based on the findings following the content analysis of student opinions regarding the importance of learning English, it was interpreted that students thought that learning English was important, even if 
for different reasons; based on the findings following the content analysis of student opinions about their expectations from the English lesson and the extent to which their expectations were met, that their expectations from the lesson were met; based on the findings obtained from the content analysis of student opinions regarding the contribution of activities performed in English lesson, that the model had a positive effect on the feelings of the learners regarding the lesson; based on the findings obtained from the content analysis of student opinions regarding their feelings throughout the activities, that the model contributed positively to their feelings about the lesson; based on the findings obtained from the content analysis of student opinions regarding the favorite activities and the reasons of their being favorites, that the activities, which students liked and their reasons for liking it differed; based on the findings obtained following the content analysis of student opinions regarding the differences between the English lessons taught before and the English lessons taught in that term, that the students realized that, the elements and activities in the environment dimension of the model were different from the lessons before; based on the findings obtained following the content analysis of student opinions aimed at rendering the English lesson more effective, that the students wanted the lessons to be taught more actively with games and music, that they wanted the model to be used in other topics and courses and that they wanted the course book, which they found boring to be used less.

\section{Discussion, conclusions and suggestions}

The results obtained from the research conducted following the needs analysis were presented according to the order of the hypothesis tested and the sub-problems sought solutions for:

1. The hypothesis, where it was claimed that there is a statistically meaningful difference in favor of the experimental group among the speaking skill pretest, post-test, permanence and permanence monitoring scores, of the experimental, control and placebo groups was rejected. Alaca (2014) and Hodges (2013) were observed to have found that the effect of the model on academic achievement was not significant in the studies they conducted with the quantum learning model. That the students' semester break started also caused a pause or decrease in their speaking skills. In the study of Gökçe (2012), findings indicating that students' success decreased due to holidays were obtained.

2. There is a statistically meaningful difference in favor of the experimental group between the selfsufficiency beliefs in foreign language pretest and post-test difference scores among the experimental, control and placebo groups on which the English curriculum developed by the quantum learning model was applied; there is a statistically meaningful difference in favor of the experimental group between the foreign language self-sufficiency beliefs post-test and permanence test difference scores of the experimental group and control group. Han and Keskin (2016) concluded that the curriculum they applied, unlike the normal curriculum, had a positive effect on speaking anxiety in a foreign language. It is also thought that the anxiety scores of all groups increased because their semester break had just ended and the permanence test was conducted on the first week of the second term and because there were some negative psychological effects stemming from the ending of holiday and transition to a new term. Sorenson (1964; cited by Sezer and Sumbas, 2018: 186) stated that the reasons such as the students' not being able to rest fully during the holidays and their holidays' not going as they wanted had a negative effect on the affective characteristics of the students.

3. There is a statistically meaningful difference in favor of the experimental group between the foreign language self-sufficiency beliefs pretest, post-test, permanence and permanence monitoring scores of the experimental, control and placebo groups on which the English curriculum developed with the quantum learning model was applied. Khajavi and Ketabi (2011) concluded that the curriculum they applied, unlike the normal curriculum, had a positive effect on self-sufficiency belief in foreign 
language. The fatigue experienced by all the students in the second term also caused them not to feel self-sufficient in foreign language. In the study of Gökçe (2012), the finding obtained was that the semester break was short for the students and that they were not truly able to rest had a negative effect on their affective properties.

The curriculum conducted in accordance with the quantum learning model, contributed positively to student behaviors. The activities in the English lessons, that were implemented appropriate for the quantum learning model, attracted the attention of the students, aroused their curiosity, motivated them, led them to participate in the activities fondly, directed them to question and research and rendered the lesson enjoyable. The main effects of the quantum learning model on students are the awakening of their curiosity, the increase in their participation and their having fun (Deporter and Hernacki, 1992). However, the students found the course book boring and had difficulty in listening texts and some writing activities in the book. Bahçeci and Yaşar (2007), in the research they conducted, reached the conclusion that students found the books used in their English classes boringThe student opinions regarding the curriculum run in compliance with the Quantum learning model are positive. It is concluded that students consider learning English important for different reasons and that in this respect, their expectations from the curriculum implemented are met. The students liked the activities performed for different reasons. That the students think that learning English is important and like the activities for different reasons may be correlated with the chaos theory. Because according to the chaos theory, there is a reason for the formation of each behavior depending on different conditions (Ford, 2016). In particular, they realized that the curriculum implemented was different from the curriculums implemented in the previous lessons, because of the activities performed and the elements in the environmental dimension of the model. They found learning based on the quantum learning model fun, often evaluated their performance at activities as good, and thought they were active; that is, they saw themselves as self-sufficient in a foreign language. The model positively influenced the students' feelings towards the English course and reduced their anxiety. Demir (2006), Hanbay (2009), Güllü (2010), Trice (2012) and Suryani (2013) concluded that quantum learning affected the students' academic achievement positively; whereas Girit (2011), Çakır (2013), Acat and Ay (2014) concluded that quantum learning model affected both the academic achievement and psychological states of learners positively. However, sometimes the students did not like the activities used in the book, got bored and suggested the books to be used less. Yildiz (2003) suggested that course books should be updated occasionally to meet the student needs. They recommended the activation of the lesson with games and music and the application of the model in other topics and lessons, for the lesson to be more effective. Çiftçi (2009) suggested that the quantum learning model was not fully implemented in the lessons

Within the framework of the conclusions reached in this study, it was suggested that the quantum learning model had a positive effect on the secondary school students' ability to speak a foreign language, their speaking anxiety and self-sufficiency. Teachers can teach their lessons more effectively thanks to the quantum learning model. First of all, they should arrange their classroom according to the quantum learning principles and adapt the curriculum of their lessons into the quantum learning. Then, they should implement the curriculum of their lessons by the quantum learning order, which occurs enrolling, experiencing, labelling, demonstrating, reviewing and celebrating steps. Also, researchers, especially ones focusing on language learning may study on other skills or components of the language, such as reading, listening or grammar. 


\section{References}

Acat, M. B. and Ay, Y. (2014). Kuantum Öğrenme Yaklaşımının İlköğretim 7. Sınıf Öğrencilerinin Fen Başarısı, Kalıcılık ve Tutumlarına Etkisinin İncelenmesi. Educational Research Association The International Journal of Research in Teacher Education, 5 (2), 11-23.

Alaca, Ö. (2014). Kuantum öğrenme modeline dayal fen bilimleri ögretiminin ortaokul ögrencilerinin akademik başarı, tutum ve kalıcılığı üzerine etkisi. (Yayımlanmamış yüksek lisans tezi). Çanakkale Onsekiz Mart Üniversitesi Eğitim Bilimleri Enstitüsü, Çanakkale.

Arslan, M. (2009). Türkiye'de Yabancı Dil Edinim Sorunu ve Yabancı Dil Olarak Türkçe. First International Symposium Sustainable Development, Sarajevo-Bosna Hersek.

Aydın, B. (1999). A Study of Sources of Foreign Language Classroom Anxiety in Speaking and Writing Classes. (Yayınlanmamış Doktora Tezi). Anadolu Üniversitesi Sosyal Bilimler Enstitüsü, Eskişehir.

Aydın, S. and Zengin B. (2008). Yabancı Dil Öğreniminde Kaygı: Bir Literatür Özeti. Journal of Language and Linguistic Studies, 4 (1), 81-94.

Ayvaz Tuncel, Z. (2011). Kuantum Öğrenme Modeli. Ö. Demirel, (Ed.), Eğitimde Yeni Yönelimler içinde (s. 289-305). Ankara: Pegem Akademi.

Bahçeci, B. and Yaşar, M. (2007). Ortaöğretim Kurumlarında İngilizce Öğretimine İlişkin Öğrenci Görüşleri. Gaziantep Üniversitesi Sosyal Bilimler Dergisi, 6 (1), 9-16.

Balc1, A. (2015). Sosyal Bilimlerde Araştırma Yöntem, Teknik ve İlkeler (11. Bs.). Ankara: Pegem Akademi.

Bekleyen, N. (2016). Çocuklara Yabancı Dil Öğretimi. Ankara: Anı Yayıncılık.

Birincioğlu Kaldar, E. (2016). English Route 7. Ankara: Pasifik Yayınları.

Can, A. (2014). SPSS ile Bilimsel Araştırma Sürecinde Nicel Veri Analizi (2. Bs.). Ankara: Pegem Akademi.

Christensen, L. B., Burke Johson, R. and Turner, L. A. (2015). Araştırma Yöntemleri: Desen ve Analiz (2. Bs.) (A. Aypay, Çev. Ed. ). Ankara: Anı Yayıncılık.

Creswell, J. W. and Clark, V. L. P. (2015). Karma Yöntem Araştırmaları Tasarımı ve Yürütülmesi (Y. Dede ve S. B. Demir, Çev. Ed.). Ankara: Anı Yayıncılık.

Çakır, C. (2013). İlköğretim 8. Sinıf Düzeyinde Maddenin Yapısı ve Özellikleri Ünitesinin Kuantum Öğrenme Modeline Dayalı Öğretimi. (Yayımlanmamış Yüksek Lisans Tezi). Balıkesir Üniversitesi Fen Bilimleri Enstitüsü, Balıkesir.

Çelebi, D. and Sarıcaoğlu, A. (2009, Mayıs). Birinci ve İkinci Dil Okuma Becerisi Arasındaki İlişkiErciyes Üniversitesi Örneği. I. Uluslararası Türkiye Eğitim Araştırmaları Kongresi'nde sunulan bildiri, Çanakkale..

Çelik, S. and Arıkan, A. (2012). Öğretmen Yetiştirme Programlarının İngilizce Öğretmen Adaylarını İlköğretimde İngilizce Öğretimine Ne Kadar Hazırladığına Yönelik Nitel Bir Araştırma. Pamukkale Üniversitesi Eğitim Fakültesi Dergisi, (32), 77-87.

Çiftçi, E. (2009). An Evaluation of Gazi University English Preparatory Classes in Terms of Quantum Teaching Model. (Yayımlanmamış Yüksek Lisans Tezi) Gazi Üniversitesi Eğitim Bilimleri Enstitüsü, Ankara.

Demir, S. (2006). Kuantum Öğrenme Modelinin Ortaöğretim Düzeyinde Öğrenen Başarlsına Etkisi 
(Gaziantep Örneği). (Yayınlanmamış Doktora Tezi), Gaziantep Üniversitesi Sosyal Bilimler Enstitüsü.

Demirel, Ö. (2012). Yabancı Dil Öğretimi. Ankara: Pegem Akademi.

Deporter, B. and Hernacki, M. (1992). Quantum Learning:Unleashing the Genius in You. NY: Random House.

Deporter, B., Reardon, M. and Singer-Nourie, S.(1999). Quantum Teaching: Orchestrating Student Success. Allyn and Bacon, A Viacom Company.

Ekici, G. (2013). Kuantum Öğrenme Yaklaşımı. G. Ekici (Ed.) Yeni Öğrenme-Öğretme Yaklaşımları ve Uygulama Örnekleri içinde (s. 462-506). Ankara: Pegem Akademi.

Emiroğlu, S. and Pınar, F. N. (2013). Dinleme Becerisinin Diğer Beceri Alanları İle İlişkisi. International Periodical For The Languages, Literature and History of Turkish or Turkic, 8 (4), 769782.

Ford, K. W. (2016). 101 Soruda Kuantum (B. Gönüleşen, Çev..). İstanbul: Alfa Yayıncılık.

Girit, D. (2011). Kuantum Öğrenme Yaklaşımının İlköğretim İkinci Kademe Öğrencilerinin Matematiğe İlişkin tutum, Kaygı Düzeyleri ve Akademik Başarıları Üzerine Etkisi. (Yayımlanmamış Yüksek Lisans Tezi). Osmangazi Üniversitesi Eğitim Bilimleri Enstitüsü, Eskişehir.

Gökçe, F. (2012). Öğretmen ve Velilerin, Öğrencilerin Okulda Geçirdikleri Zaman, Ders ve Dinlenme Süreleri ile Tatiller ve Okul Dönemleri Konusundaki Görüşleri. Kuram ve Uygulamada Eğitim Bilimleri, 12 (4), 2541-2560.

Göktaş, Y., Küçük, S., Aydemir, M., Telli, E., Arpacık, Ö. and Yıldırım, G. (2012). Educational technology research trends in Turkey: A content analysis of the 2000-2009 decade. Educational Sciences: Theory and Practice, 12 (1), 191-199.

Güllü, A. (2010). Kuantum Öğrenme Modelinin Orta Öğretim Düzeyinde Öğrenci Başarısına Etkisi (Konya Örneği). (Yayımlanmamış Yüksek Lisans Tezi), Selçuk Üniversitesi Eğitim Bilimleri Enstitüsü, Konya.

Han, T. and Keskin, F. (2016). Using a Mobile Application (WhatsApp) to Reduce EFL Speaking Anxiety. Gist Education and Learning Research Journal, 12, 29-50.

Hanbay, O. (2009). Kuantum Öğrenme Temelli Öğreterek Öğrenme Yönteminin İkinci Yabancı Dil Olarak Almancanın Öğrenilmesine Etkisi. Dicle Üniversitesi Ziya Gökalp Eğitim Fakültesi Dergisi, 1 (12), 17-27.

Hancı Yanar, B. and Bümen, T. N. (2012). İngilizce İle İlgili Öz-yeterlik İnancı Ölçeğinin Geliştirilmesi. Kastamonu Ĕ̈itim Dergisi, 20 (1), 97-110.

Hodges, J. A. (2013). The Impact of Brain-based Strategies: One School's Perspective. (The Unpublished Doctoral Dissertation). Walden University, College of Education.

Horwitz, E. K., Horwitz, M. B., and Cope, J. (1986). Foreign Language Classroom Anxiety. The Modern Language Journal, 70 (2), 125-132.

Johnson, A. P. (2015). Eylem Araştırması El Kitabı (Y. Uzuner ve M. Özten Anay, Çev.). Ankara: Anı Yayınc1lik.

Karasar, N. (2012). Bilimsel Araştırma Yöntemleri. Ankara: Nobel Akademik Yayıncılık.

Khajavi, Y. and Ketabi, S. (2011). Influencing EFL Learners' Reading Comprehension and Self-efficacy 
Beliefs: The Effect of Concept Mapping Strategy. Porta Linguarum, (17), 9-27.

Larsen - Freeman, D. (2003). Techniques and Principles in Language Teaching. Oxford University Press.

Maxom, M. (2009). Teaching English as a Foreign Language for Dummies. John Wiley and Sons, Ltd.

Merriam, S. B. (2013). Nitel Araştırma (3. Bs.) (S., Turan Çev. Ed.). Ankara: Nobel Akademi Yayıncilik.

Meydan, C. H. and Şeşen, H. (2015). Yapısal Eşitlik Modellemesi AMOS Uygulamaları (2. Bs.). Ankara: Detay Yayıncilik.

Nassaji, H. (2017). Diversity of research methods and strategies in language teaching research. Language Teaching Research, 21 (2), 140-143.

Öner, G. and Gedikoğlu, T. (2007). Ortaöğretim Öğrencilerinin İngilizce Öğrenimlerini Etkileyen Yabanc1 Dil Kaygısı. Gaziantep Üniversitesi Sosyal Bilimler Dergisi, 6 (2), 144-155.

Öztürk, G. (2012). Foreign Language Speaking Anxiety and Learner Motivation: A Case Study at a Turkish State University. (Yayımlanmamış Yüksek Lisans Tezi) ODTÜ, Ankara.

Saday, A. (2007). İlköğretimde Aktif Öğrenme Kuramı Destekli İngilizce Öğretim Yöntemiyle İngilizce Konuşma Becerisinin Geliştirilmesine İlişkin Bir Araşstırma. (Yayımlanmamış Yüksek Lisans Tezi). Dicle Üniversitesi Sosyal Bilimler Enstitüsü, Diyarbakır.

Saltan, F. (2003). EFL Speaking Anxiety: How do Students and Teachers Perceive it? (Yayınlanmamış Yüksek Lisans Tezi). ODTÜ, Ankara.

Sezer, Ö. and Sumbas, E. (2018). Lise Öğrencilerinin Yaz Tatillerini Kullanım Biçimlerinin Bazı Değişkenler Açısında İncelenmesi. İnönü Üniversitesi Uluslararası Sosyal Bilimler Dergisi, 7 (1), 173-189.

Suryani, N. (2013). Improvement of Students' History Learning Competence through Quantum Learning Model at Senior High School in Karanganyar Regency, Solo, Central Java Province, Indonesia. Journal of Education and Practice, 4 (14) 55-64.

Tin, T. B. (2013). Exploring the Development of "Interest" in Learning English as a Foreign/Second Language. RELC Journal, 44 (2), 129-146.

Trice, T. Y. (2012). Quantum Learning Making Progious Strides in Education. The Unpublished Doctoral Dissertation, Trevecca Nazarene University, School of Education.

Yıldırım, A. and Şimşek, H. (2004). Sosyal Bilimlerde Nitel Araştırma Yöntemleri (4. Bs.). Ankara: Seçkin Yayınc1lı.

Yıldız, Ö. (2003). Türkiye’de Tarih Öğretiminin Sorunları ve Çağdaş Çözüm Önerileri. Sosyal Bilimler Enstitüsü Dergisi, (15), 181-190. 


\section{Kuantum öğrenme modelinin ortaokul öğrencilerinin yabancı dilde konuşma becerisi, konuşma kaygısı ve öz-yeterliği üzerindeki etkisi}

\section{$\ddot{\mathbf{O z}}$}

Yabancı dil olarak İngilizceyi öğrenme, dünyada farklı sebeplerden dolayı önemli görülmektedir. Ancak Türkiye'de büyük emeklere ve yatırımlara karşın İngilizce öğrenme oranı ve seviyesi istenilen düzeyde değildir. Yapılan doktora tezinde amaç; kuantum öğrenme modeline dayalı olarak yürütülen İngilizce öğretim programının ortaokul öğrencilerinin yabancı dilde konuşma becerisi, konuşma kaygısı ve öz-yeterlik üzerindeki etkisini incelemektir. Araştırma konusunun belirlenmesinde ve kullanılacak model ve yöntemin seçiminde yapılan ihtiyaç analizi etkili olmuştur. Araştırma deneysel modelde desenlenmiştir. Deneme modeli, 3x4 (deney, kontrol ve plasebo grubu X ön test, son test, kalıcılık testi, kalıcılı̆̆ı izleme testi) yarı-deneysel modeldir. Ana uygulama öncesi, bir yedinci sınıfta pilot uygulama gerçekleștirilmiş ve ana uygulamaya yönelik dönüt alınmıştır. Araştırmanın çalışma grubunu başarı düzeyi "orta" olan bir ortaokulun 7. sınıfları oluşturmuştur. Küme örnekleme yöntemiyle üç sınıftan biri kontrol, biri deney ve biri de plasebo grubu olarak atanmıştır. Gruplarda öğretimin yürütülmesi ön-test ve son-testin uygulamasıyla birlikte on hafta sürmüştür. Sonuç olarak, Kuantum öğrenme modeline göre yürütülen program, öğrencilerin İngilizce ile ilgili öz-yeterlik inançlarını artırmış ve İngilizce konuşma kaygılarını azaltmıştır. Ancak modelin konuşma becerisine sağladığı katkı istatistiksel olarak anlamlandırılamamıștır. Kuantum öğrenme modeline göre ișlenen İngilizce derslerindeki etkinlikler öğrencilerin dikkatlerini çekip merakını uyandırmış, isteklendirmiș, etkinliklere katılımı artırmıș, sorgulama ve araștırmaya yönlendirmiş ve dersi eğlenceli hale getirmiştir. Kuantum öğrenme modeliyle yürütülen programa ilişkin öğrenci görüşleri olumlu yönde olmuştur.

Anahtar sözcükler: İngilizce öğretimi; konuşma becerisi; konuşma kaygısı; Kuantum öğrenme; öz-yeterlik.

\section{AUTHOR BIODATA}

Mehmet ALTIN, born in Kırşehir in 1987, completed primary, secondary and high school education in Kırşehir province in Turkey. He started his undergraduate education at the Department of English Language Education at Gazi University in 2005. Then, he was appointed as an English Teacher at a primary school in 2009. In 2012, he started to work as a research assistant at the Department of Curriculum and Instruction at Aydın Adnan Menderes University. He completed his master's degree, in 2014, and PhD degree, in 2018, at the Department of Curriculum and Instruction at Aydın Adnan Menderes University. He is interested in the fields of curriculum development and evaluation, teacher training, learning-teaching theories and approaches and foreign language education.

Asuman Seda SARACALOĞLU is a graduate at the Department of Curriculum and Instruction of Ankara University and successfully completed her master's and doctoral studies at the Department of Curriculum and Instruction of the same university. After working as an assistant professor at Ege University in 1994, she became an associate professor in the field of curriculum development in 1995. In 2002, she was appointed as a professor to the Department of Curriculum and Instruction at Adnan Menderes University. She served as the vice-rector and dean of education faculty at Aydın Adnan Menderes University. There are hundreds of academic studies in the fields of curriculum development and evaluation, teacher training, learning-teaching theories and approaches and comparative education. 